\title{
PENGARUH PROMOSI PENGEMBANGAN KARIER TERHADAP PRODUKTIVITAS KERJA PADA BADAN KEPEGAWAIAN DAN PENGEMBANGAN SUMBER DAYA MANUSIA (BKPSDM) KABUPATEN LAMPUNG BARAT
}

\author{
Kristiawan $^{(1)}$, Ahirrudin ${ }^{(2)}$, Maria Elina ${ }^{(3)}$ \\ Fakultas Ekonomi Universitas Sang Bumi Ruwa Jurai \\ awan.kristiawan@gmail.com,ahirrudin@fe.saburai.ac.id,maria.elina@fe.saburai.ac.id
}

\begin{abstract}
Abstrak. Program pengembangan karier atau promosi memberikan kesempatan kepada pegawai untuk menyelidiki minat, kebutuhan. dan pilihan karier dalam perusahaan. Melalui pengembangan karier pegawai dibantu untuk mengembangkan kecakapan dan kemampuan yang diperlukan sasaran jabatan. Produktivitas kerja yang tinggi bagi pegawai sangat diperlukan dalam setiap usaha mencapai tujuan organisasi. Masalah pada penelitian ini adalah masih kurang maksimalnya produktifitas kerja dalam pekerjaan Pegawai Badan Kepegawaian dan Pengembangan Sumber Daya Manusia (BKPSDM) Kabupeten Lampung Barat. Tujuan penelitian ini adalah untuk mengetahui pengaruh promosi pengembangan karier terhadap produktivitas kerja pegawai pada Badan Kepegawaian dan Pengembangan Sumber Daya Manusia (BKPSDM) Kabupaten Lampung Barat. Hasil pengujian menunjukkan bahwa kontribusi variable independen terhadap variable dependen adalah sebesar 94,3\%, sedangkan sisanya sebesar 5,7 \% ditentukan oleh variabel lain yang tidak teridentifikasi dalam penelitian ini. Dari pengolahan data statistik maka diperoleh persamaan regresi linier sederhana adalah $Y=1,142+0,590(\mathrm{X})$ serta dapat diketahui bahwa tingkat signifikansi sebesar $0,00<0,05$ dengan nilai $\mathrm{t}_{\text {hitung }}>\mathrm{t}_{\text {tabel }}$ yaitu $19,060>2,068$, dengan demikian hipotesis diterima yang berarti promosi berpengaruh terhadap produktifitas pada Badan Kepegawaian dan Pengembangan Sumber Daya Manusia Kabupaten Lampung Barat.
\end{abstract}

Kata kunci: Karier, Promosi, Produktivitas, Program.

\section{PENDAHULUAN}

Pelaksanaan tugas dan pekerjaan merupakan suatu kewajiban bagi para anggota dalam suatu organisasi, baik dalam organisasi pemerintah maupun non pemerintah. Dalam pelaksanaan tugas dan kewajiban tersebut terdapat suatu tujuan yang sama yakni mengharapkan suatu hasil yang baik serta memuaskan sesuai dengan apa yang telah ditentukan sebelumnya. Untuk mendapatkan suatu hasil kerja yang baik sesuai dengan tujuan, maka setiap organisasi mempunyai suatu aturan yang dituangkan dalam bentuk kebijakan. Kebijakan ini dibuat dengan maksud agar tiap komponen organisasi melaksanakan tugas sesuai dengan tujuan yang ditetapkan.

Pegawai negeri sipil merupakan Sumber Daya Aparatur Negara yang bertugas memberikan pelayanan masyarakat secara profesional, jujur, adil dan merata dalam penyelenggaraan tugas Negara, pemerintah dan pembangunan yang dilandasi kesetiaan dan ketaatan kepada pancasila dan undang-undang dasar 1945. Kedudukan dan peranan pegawai negeri sipil di indonesia dirasakan semakin penting untuk menyelenggarakan pemerintahan dan pembangunan dalam usaha mencapai tujuan nasional yaitu mewujudkan masyarakat madani yang taat hukum, beradapan moderen, demokratis, makmur, adil dan bermoral tinggi.

Badan Kepegawaian dan Pengembangan Sumber Daya Manusia (BKPSDM) Kabupaten Lampung Barat, dalam melaksanakan tugas pokok Badan Kepegawaian dan Pengembangan Sumber Daya Manusia Kabupaten Lampung Barat 
memiliki fungsi penyiapan dan penyusunan peraturan perundang-undangan daerah di bidang kepegawaian. Perencanaan dan pengembangan kepegawaian daerah. Penyiapan kebijakan teknis pengembangan kepegawaian daerah. Mempunyai Tugas Pokok Melaksanakan urusan Pemerintahan Daerah dalam penyusunan dan pelaksanaan kebijakan daerah bidang Kepegawaian, Melaksanakan tugas-tugas lain yang diberikan oleh Bupati sesuai dengan bidang tugasnya. Selanjutnya Fungsi Pengumpulan, pengelolaan dan pengendalian data berbetuk database serta analisa data untuk penyusunan program kegiatan ; Perencanaan strategis pada Badan Kepegawaian dan Pengembangan Sumber Daya Manusia ; Perumusan kebijakan teknis bidang kepegawaian.

Selain itu didalam Badan Kepegawaian dan Pengembangan Sumber Daya Manusia (BKPSDM) Kabupaten Lampung Barat menerapkan pokok-pokok untuk memajukan Manajemen Sumber Daya Manusia dengan menerapkan suatu sistem reward and punishment. Reward diberikan kepada pegawai yang melakukan prestasi lebih atau menciptakan inovasi-inovasi dalam pekerjaannya. Sedangkan punishment diberikan kepada pegawaipegawai yang melakukan penyimpangan atau pelanggaran dalam pekerjaannya.

Akan tetapi promosi dan rencana karier pegawai belum didasarkan pada pola produktivitas kerja para pegawai, sehingga para pegawai kurang obyektif dalam bertanggung jawab terhadap pekerjaannya dikarenakan kurangnya promosi dan rencana karier pegawai terhadap pekerjaan yang telah menjadi tanggung jawabnya.

Program pengembangan karier memberikan kesempatan kepada pegawai untuk menyelidiki minat, kebutuhan. dan pilihan karier dalam perusahaan. Melalui pengembangan karier pegawai dibantu untuk mengembangkan kecakapan dan kemampuan yang diperlukan sasaran jabatan.

Keterkaitan antara pengembangan karier dengan tingkat produktivitas kerja perlu diperhatikan oleh pihak perusahaan. Peranan Pengembangan karier dinas/satker yang baik dan berjalan efektif akan menghasilkan pegawai yang termotivasi untuk menghasilkan produktivitas lebih tinggi.

Belum ada secara rinci dan terpadu usaha-usaha yang harus dilakukan untuk mencapai produktivitas kerja pegawai yang ada dalam organisasi Badan Kepegawaian dan Pengembangan Sumber Daya Manusia (BKPSDM) Kabupaten Lampung Barat. dengan mengetahui besarnya pengaruh dari promosi jabatan, dan rencana pengembangan karier maka para pimpinan dan pihak-pihak terkait di lingkungan Badan Kepegawaian dan Pengembangan Sumber Daya Manusia (BKPSDM) Kabupaten Lampung Baratakan mudah dalam melakukan langkah-langkah pembinaannya.

Dari uraian tersebut maka peneliti tertarik untuk melakukan peneliti dengan judul: "Pengaruh Promosi Pengembangan Karier terhadap Produktivitas Kerja Pegawai pada Badan Kepegawaian dan Pengembangan Sumber Daya Manusia (BKPSDM) Kabupaten Lampung Barat".

\section{KAJIAN TEORI}

\section{Definisi Manajemen Sumber Daya Manusia}

Wilson Bangun (2012), menejelaskan bahwa untuk mendefisinikan manajemen sumber daya manusia, perlu pemahaman dua fungsi, anatara lain, fungsi-fungsi manajerial (managerial functions) dan operasional (operational functions). Berdasarkan sumber daya-sumber daya yang ada pada organisasi, maka manajemen 
dapat dibagi ke dalam manajemen sumber daya manusia, keuangan, operasi/produksi, dan pemasaran.

Fungsi-fungsi manajemen tersebut akan berkaitan dengan setiap bidang manajemen. Manajemen sumber daya manusia melakukan kegiatan perencanaan, pengorganisasian, penyusunan personalia, penggerakan, dan pengawasan terhadap fungsi-fungsi operasionalnya, untuk mencapai tujuan organisasi. Demikian pula, manajemen pada bidang-bidang lainnya melakukan hal sama pada arah yang berbeda, tetapi memiliki keterkaitan antara satu dengan lainnya untuk mencapai tujuan organisasi secara keseluruhan. Tentunya, fungsi operasional pada setiap bidang manajemen tersebut berbeda.

Fungsi operasional manajemen sumber daya manusia berkaitan dengan pengelolahan manusia dalam organisasi, seperti pengadaan, pengembangan, pemberian kompensasi, pengintergrasian, pemeliharaan, dan pemisahan tenaga kerja. Demikian pula dengan manajemen keuangan, operasi/produksi, dan pemasaran, yaitu melaksanakan kegiatankegiatan manajemen terhadap fungsi-fungsi operasionalnya masing-masing untuk mencapai tujuan organisasi.

Manajemen sumber daya manusia berkaitan dengan pengelolahan manusia melalui aktivitas-aktivitas organisasi dan fungsi-fungsi operasionalnya. Dengan demikian, Wilson Bangun (2012), mendefinisikan manajemen sumber daya manusia adalah: "sebagai suatu proses perencanaan, pengorganisasian, penyusunan staf, penggerakan, dan pengawasan, terhadap pengadaan, pengembangan, pemberian kompensasi, pengintregasian, pemeliharaan, dan pemeliharaan, dan pemisahan tenaga kerja untuk mencapai tujuan organisasi”.

Adapun pengertian Manajemen Sumber Daya Manusia menurut Melayu SP. Hasibuan (2010), adalah ilmu dan seni mengatur hubungan dan peranan tenaga kerja agar efektif dan efisien membantu terwujudnya tujuan perusahaan, karyawan, dan masyarakat". Sutrisno (2013), mendefiniskan: "manajemen sumber daya manusia sebagai suatu perencanaan, pengorganisasian, pengaraha, dan pengwasan atas pengadaan, pengembangan, kompensasi, pengintegrasian, pemeliharaan, dan pemutusan hubungan kerjaa dengan maksud untuk mencapai tujuan organisasi perusahaan secara terpadu.

\section{Definisi Promosi}

Kesempatan untuk maju di dalam organisasi sering disebut sebagai promosi (naik pangkat). Kata mutasi atau pemindahan oleh sebagian masyarakat sudah banyak di kenal. Menurut arti katanya maka istilah pemindahan meliputi segala pemindahan jabatan seorang karyawan dalam arti umum. Jadi ke dalam istilah tersebut termasuk bukan saja perubahan jabatan yang setingkat yang tidak mengurangi/menaikkan baik kekuasaan maupun tanggung jawabnya, tetapi juga promosi (kenaikan) dan demosi (penurunan).

Hal ini sesuai dengan batasan yang terdapat di dalam kamus managemen, yaitu pemindahan adalah suatu perubahan dalam penunjukan pekerjaan, pemindahan dapat mengandung kenaikan pangkat, penurunan pangkat/tidak ada perubahan dalam status dan tanggung jawab (Moekijat, 2008). Akan tetapi dalam penelitian ini mutasi yang dimaksudkan adalah yang menekan pada perubahan jabatan yang setingkat yang tidak mengurangi atau menaikkan baik kekuasaan maupun tanggung jawabnya.

Menurur Alex S. Nitisemito (2012) mutasi atau pemindahan adalah kegiatan dari pimpinan perusahaan untuk memindahkan karyawan dari suatu pekerjaan ke pekerjaan lain yang dianggap setingkat atau sejajar. Mutasi yang 
dimaksudkan ini untuk menempatkan pemegang jabatan tertentu kepada jabatan yang lebih tepat sesuai dengan keinginan, pengetahuan, dan keahliannya dengan harapan pada jabatan yang baru itu dia akan dapat bekerja sama dengan sesama karyawan maupun atasannya.

Dengan demikian, mutasi atau pemindahan merupakan suatu cara yang dilakukan oleh lembaga dalam tingkat/jabatan yang sejajar (horizontal) yang bertujuan untuk menempatkan karyawan pada posisi yang sesuai sehingga dapat merangsang dan mendorong karyawan yang bersangkutan untuk bekerjasama dan bekerja penuh semangat, sehingga tujuan perusahaan dapat tercapai.

\section{Produktivitas Kerja}

Pengertian produktifitas di atas, dapat disimpulkan menjadi suatu filosofi dan sikap mental yang timbul dari motivasi yang kuat dari masyarakat, yang secara terus-menerus berusaha meningkatkan kualitas kehidupan. Menurut George J. Washin (2008) Produktifitas mengandung dua konsep utama, yaitu efisiensi dan efektivitas. Efisiensi mengukur tingkat sumber daya, baik manusia, keuangan, maupun alam yang dibutuhkan untuk memenuhi tingkat pelayanan yang dikehendaki, efektivitas mengukur hasil mutu pelayanan yang dicapai.

Sedarmayanti (2011) menyatakan bahwa produktifitas adalah: "Suatu sikap mental yang selalu mempunyai pandangan bahwa mutu kehidupan hari ini harus lebih baik dari kemarin dan hari esok harus lebih baik dari hari ini."M.Sinungan ( 2009) mendefenisikan produktifitas sebagai hubungan antara hasil nyata maupun fisik (barang-barang dan jasa) dengan masukan yang sebenarnya. Tunggal (2010) mendefenisikan produktifitas sebagai prestasi seseorang pekerja atau sistem operasi dibandingkan dengan sumber daya yang digunakan keluaran dibagi dengan masukan. Menurut Herjanto (2009) Produktivitas merupakan suatu ukuran yang menyatakan bagaimana baiknya sumber daya diatur dan dimanfaatkan untuk mencapai hasil yang optimal.

\section{Faktor Faktor yang Mempengaruhi Produtktifitas kerja}

Menurut Pandji Anoraga (2009), ada 10 faktor yang sangat diinginkan oleh para karyawan untuk meningkatkan produktivitas kerja karyawan, yaitu:

1. pekerjaan yang menarik

2. upah yang baik

3. keamanan dan perlindungan dalam pekerjaan

4. etos kerja dan

5. lingkungan atau sarana kerja yang baik

6. promosi dan perkembangan diri mereka sejalan dengan perkembangan perusahaan

7. merasa terlibat dalam kegiatan-kegiatan organisasi

8. pengertian dan simpati atas persoalanpersoalan pribadi

9. kesetiaan pimpinan pada diri sipekerja

10. Disiplin kerja yang keras

\section{METODE PENELITIAN}

\section{Objek Penelitian}

Objek penelitian ini adalah pegawai di Badan Kepegawaian dan Pengembangan Sumber Daya Manusia (BKPSDM) Kabupaten Lampung Barat, yang beralamat di Jln.Mawar No.3 Komplek Pemda Liwa Lampung Barat. Penelitian ini dilaksanakan dari bulan April sampai dengan Juli 2018.

\section{Metode dan Teknik Pengumpulan Data}

Dalam penelitian ini jenis data yang diperlakukan adalah :

a. Data Primer 
Data primer merupakan data dasar yang akan diperoleh langsung tanpa perantara orang atau lembaga lain sebagai pihak ketiga. Data primer ini diperoleh dengan wawancara melalui responden dengan menggunakan daftar pertanyaan.

\section{b. Data Sekunder}

Data skunder merupakan data yang diperoleh melalui orang lain yang berhubungan dengan permasalahan yang dipecahkan. Data sekunder ini diperoleh melalui cara studi dokumenter yaitu mengumpulkan dan mempelajari brosurbrosur serta dokumen organisasi.

\section{Sampel dan Populasi}

Sampel penelitian adalah sebagian dari populasi yang mewakili sifat dan karakter yang sama. Dengan mengambil sampel dimaksudkan untuk menyederhanakan jumlah subjek yang harus diteliti, tetapi hasil penelitian terhadap sampel itu akan digeneralisasikan pada populasi yang ada. Untuk menentukan banyak sampel, penelitian menggunakan pedoman dari pendapat Suharsimi Arikunto (2010), maka apabila subyeknya kurang dari 100, lebih baik diambil semua sehingga penelitiannya merupakan penelitian populasi. Selanjutnya jika jumlah subyeknya besar, dapat diambil $10 \%-15 \%$ atau 20\%-25\% atau lebih. Adapun jumlah sampel yang diperoleh adalah seluruh populasi pegawai yang berjumlah 24 orang pegawai pada Badan Kepegawaian dan Pengembangan Sumber Daya Manusia (BKPSDM) Kabupaten Lampung Barat.

\section{Metode Analisis Data}

Untuk pengolahan data dalam bentuk tabulasi hasil jawaban responden kemudian dilakukan analisis data melalui metode analisis secara kualitatif dan analisa kuantitatif. Analisis kualitatif dilakukan dengan analisis tabel tunggal atau secara parsial yang akan menggambarkan kriteria masing-masing variabel. Analisis kuantitatif yang dilakukan berdasarkan data primer yang diperoleh dari penyebaran instrument (daftar pertanyaan) kepada sampel, dan untuk mengetahui pengaruh dari variabel bebas (independent variable) terhadap variabel terikat (dependent variable).

Persamaan Regresi Linear Sederhana menentukan persamaan regresi linear sederhana untuk X :

$$
Y=a+b X+e
$$

Keterangan:

$$
\begin{aligned}
& \mathrm{Y}=\text { Produktivitas kerja } \\
& \mathrm{a}=\text { Konstanta } \\
& \mathrm{b}=\text { Koefisien regresi } \mathrm{X} \\
& \mathrm{X}=\text { Promosi Pengembangan Karier } \\
& \mathrm{e}=\text { Faktor kesalahan }
\end{aligned}
$$

Untuk mengetahui besarnya pengaruh, penghitungan koefisien korelasi tersebut kemudian dilanjutkan dengan Rumus Koefisien Determinasi atau Koefisien Penentu (KP):

$$
K P=(r)^{2} x 100 \%
$$

Untuk menguji secara hipotesis secara parsial digunakan Uji t dengan rumus :

$$
t_{\text {hitung }}=\frac{r \sqrt{N-2}}{\sqrt{1-r^{2}}}
$$

Keterangan:

$$
\begin{array}{ll}
\mathrm{t}_{\text {hitung }} & =\text { Nilai } \mathrm{t} \\
\mathrm{r} & =\text { Koefisien Korelasi } \\
\mathrm{N} & =\text { Jumlah responden } \\
& \quad \text { (Sugiyono, 2008). }
\end{array}
$$

Kriteria untuk Uji $t$ adalah sebagai berikut : 
a) Jika $t_{\text {hitung }}>t_{\text {tabel }}$ maka Ha diterima dan Ho ditolak.

b) Jika $\mathrm{t}_{\text {hitung }} \leq \mathrm{t}_{\text {tabel }}$ maka Ha ditolak dan Ho diterima.

Taraf signifikan dalam penelitian ini digunakan $\alpha=0,05$ atau 5\%. Yang dimaksud dengan Hipotesis nol (Ho) dan Hipotesis alternatif (Ha) adalah :

Ho $=r \leq 0=$ Berarti tidak ada pengaruh promosi pengembangan karier terhadap produktivitas kerja

$\mathrm{Ha}=\mathrm{r}>0=$ Berarti ada pengaruh promosi pengembangan karier terhadap produktivitas kerja.

\section{HASIL DAN PEMBAHASAN}

Data penelitian yang telah dikumpulkan kemudian diolah untuk menguji kualitas data berupa uji validitas dan reliabilitas. Dari hasil uji validitas yang dilakukan menunjukkan bahwa koefisien korelasi pearson moment untuk setiap item butir pertanyaan dengan skor total variabel promosi $(\mathrm{X})$, dan produktifitas $(\mathrm{Y})$ signifikan pada tingkat signifikan $\alpha 0,05$. Dengan demikian dapat diinterprestasikan bahwa setiap item indikator instrumen masing-masing variabel tersebut valid. Uji validitas ditunjukkan pada Tabel 1. Dan Tabel 2.

Tabel 1. Hasil Uji Validitas Instrumen Variabel Promosi

\begin{tabular}{lccc}
\hline Indikator & $\mathrm{r}$ hitung & $\mathrm{r}$ tabel & Keterangan \\
\hline $\mathrm{X} 1$ & 0.721 & 0.514 & Valid \\
X2 & 0.975 & 0.514 & Valid \\
X3 & 0.875 & 0.514 & Valid \\
X4 & 0.975 & 0.514 & Valid \\
X5 & 0.768 & 0.514 & Valid \\
X6 & 0.825 & 0.514 & Valid \\
X7 & 0.875 & 0.514 & Valid \\
X8 & 0.875 & 0.514 & Valid \\
\hline
\end{tabular}

Nilai $r$ hitung lingkungan kerja lebih besar dari $r$ tabel (0.514), sehingga seluruh indikator dinyatakan valid.

Tabel 2. Hasil Uji Validitas Instrumen Variabel Produktifitas kerja

\begin{tabular}{lrrc}
\hline Indikator & $\mathrm{r}$ hitung & $\mathrm{r}$ tabel & Keterangan \\
\hline Y1 & 0.922 & 0.514 & Valid \\
Y2 & 0.960 & 0.514 & Valid \\
Y3 & 0.922 & 0.514 & Valid \\
Y4 & 0.877 & 0.514 & Valid \\
Y5 & 0.877 & 0.514 & Valid \\
\hline
\end{tabular}

Tabel 2. Menunjukkan hasil perhitungan seluruh indikator untuk variabel produktifitas kerja adalah lebih besar dari $r$ tabel, sehingga seluruh indikator dinyatakan valid.

\section{Uji Reliabilitas Data}

Nilai reliabilitas konsistensi internal menunjukkan bahwa koefisien Alpha Cronbach dinyatakan reliabel karena lebih besar dari 0,60. Dengan demikian item pengukuran pada masing-masing indikator dalam variabel-variabel penelitian dinyatakan reliabel dan selanjutnya dapat digunakan dalam penelitan.

\section{Analisis Kuantitatif}

Dari pengolahan data statistik maka diperoleh persamaan regresi linier sederhana adalah $\mathrm{Y}=1,142+0,590(\mathrm{X})$. Nilai konstanta yang diperoleh sebesar 1,142 , hal ini berarti bahwa jika variabel independen (promosi) adalah bernilai nol, maka besarnya produktifitas yang terjadi adalah 1.142. Nilai koefisien regresi variabel promosi (X) sebesar 0,590, hal ini menunjukkan bahwa setiap kenaikan satu satuan promosi akan mengakibatkan kenaikan produktifitas sebesar 0,590.

Koefisien determinan $\left(\mathrm{R}^{2}\right)$ digunakan untuk mengetahui kontribusi variabel bebas dalam menjelaskan variabel terikat. 
Semakin besar nilai koefisien determinasi maka menunjukkan semakin besar pula pengaruh variabel terikat terhadap variabel bebas. Hasil pengujian menunjukkan bahwa nilai $R$ square sebesar 0.943 . Nilai $R$ square ini menunjukkan bahwa besarnya kontribusi variabel independen terhadap variabel dependen adalah sebesar 94,3\%, sedangkan sisanya sebesar $5,7 \%$ ditentukan oleh variabel lain yang tidak teridentifikasi dalam penelitian ini.

Pengujian hipotesis dilakukan untuk menjawab model kelayakan hipotesis penelitian. Pengujian dilakukan dengan menggunakan uji $\mathrm{t}$ pada tingkat kepercayaan 95\% atau $\alpha$ sebesar 0,05. Hasil pengujian yang diperoleh dapat menjawab hipotesis yang menyatakan "promosi berpengaruh terhadap produktifitas ". Dapat diketahui bahwa tingkat signifikansi sebesar $0,00<0,05$ dengan nilai $t_{\text {hitung }}>$ $t_{\text {tabel }}$ yaitu 19,060 $>2,068$, dengan demikian hipotesis diterima yang berarti promosi berpengaruh terhadap produktifitas pada Badan Kepegawaian dan Pengembangan Sumber Daya Manusia Kabupaten Lampung Barat.

\section{KESIMPULAN DAN SARAN}

\section{Kesimpulan}

Berdasarkan hasil penelitian dapat disimpulkan bahwa hasil pengujian menunjukkan nilai $R$ square sebesar 0,943 , maka besarnya kontribusi variabel independen terhadap variabel dependen adalah sebesar $94,3 \%$, sedangkan sisanya sebesar 5,7\% ditentukan oleh variabel lain yang tidak teridentifikasi dalam penelitian ini. Pengujian dilakukan dengan menggunakan uji $t$ yang menunjukkan bahwa promosi terhadap produktifitas kerja pada Badan Kepegawaian dan Pengembangan Sumber Daya Manusia Kabupaten Lampung Barat. Pengujian dilakukan dengan menggunakan uji t pada tingkat keyakinan signifikansi $\alpha 0,05$. Dari hasil olah data dapat diketahui bahwa tingkat signifikansi sebesar $0,00<0,05$ dengan nilai $t_{\text {hitung }}>t_{\text {tabel }}$ yaitu 19,060 > 2,068, dengan demikian hipotesis diterima yang berarti promosi berpengaruh terhadap produktifitas kerja pada Badan Kepegawaian dan Pengembangan Sumber Daya Manusia Kabupaten Lampung Barat.

\section{Saran}

Adapun saran yang diajukan peneliti adalah sebagai berikut:

1. Badan Kepegawaian dan Pengembangan Sumber Daya Manusia Kabupaten Lampung Barat hendaknya mempertimbangan promosi bagi pegawai yang mempuntai produktifitas lebih.

2. Badan Kepegawaian dan Pengembangan Sumber Daya Manusia Kabupaten Lampung Barat hendaknya memberikan kesempatan bagi pegawai untuk di promosikan ke jenjang yang lebih tinggi sesuai dengan pendidikan dan pengalaman kerja.

3. Badan Kepegawaian dan Pengembangan Sumber Daya Manusia Kabupaten Lampung Barat hendaknya memberikan reward kepada pegawainya sesuai dengan kemampuan dan kualitas yang dimiliki sesuai dengan kinerjanya.

\section{DAFTAR PUSTAKA}

Algifari. 2009. Metode Penelitian. Bandung: Alfabeta.

Arikunto, Suharsimi. 2010. Prosedur Penelitian. Jakarta: Penerbit Bina Aksara.

Bangun, Wilson.2012. Manajemen Tenaga Kerja Indonesia. Jakarta : Bumi Aksara. 
Budiyono. 2009. Metode Penelitian dan Survey. Jakarta: Penerbit LP3S.

Edwin B., Filippo. 2008. Manajemen Personalia Jilid I. Diterjemahkan oleh Moh. Masud. Jakarta: Erlangga.

Ferdinand. 2008. Metode Penelitian Manajemen. Semarang: Badan Penerbit Universitas Diponegoro.

Hasibuan. 2002. Evaluasi Kinerja Sumber Daya Manusia. Jakarta: RefikaAditama.

Herjanto. 2009. Manajemen Sumber Daya Manusia, Edisi Ketiga. Yogyakarta: STIE YKPN.

Kurniawan. 2005. Manajemen Sumber Daya Manusia. Jakarta: PT. BumiAksara.

Moekijat. 2008. Manajemen Sumber Daya Manusia. Jakarta: Ghalia Indonesia.

Nitisemito, Alex S. 2012. Manajemen Personalia. Yogyakarta: UGM Press.

Panggabean. 2008. Manajemen Personalia. Yogyakarta: UGM Press.

Purnamasari. 2008. Statistika Untuk Penelitian. Bandung: Alfabeta.

Sedarmayanti. 2011. Sumber Daya Manusia dan Produktivitas kerja. Bandung: Mandar Maju.

Sinungan, M. 2009. Manajemen Sumber Daya Manusia untuk Keunggulan Bersaing Organisasi. Jakarta: Graha Ilmu.

Sugiyono. 2010. Metode Penelitian Kualitatif dan Kuantitatif $R \& D$. Bandung: Alfabeta.

Sutrisno, Hadi. 2004. Metodologi Research 3. Yogyakarta: ANDI.
Sutrisno, Edy. 2010. Manajemen Sumber Daya Manusia. Jakarta: Kencana.

Tunggal. 2010. Motivasi Kepemimpinan dan Efektivitas Kelompok. Jakarta: Penerbit Rineka Cipta.

Washin, George J. 2008. Basic Econometrics. Mc Graw-Hill Kogakusha. Japan: Ltd Tokyo. 